\title{
PERSEPSI DAN PERILAKU SWAMEDIKASI PENYAKIT JAMUR KULIT DI KELURAHAN PANJANG WETAN KOTA PEKALONGAN TAHUN 2020
}

\section{PERCEPTION AND BEHAVIORS OF SKIN FUNGAL DISEASE SELF-MEDICATION IN PANJANG WETAN VILLAGE, PEKALONGAN CITY IN 2020}

\author{
Viya Amalia ${ }^{1}$, Ainun Muthoharoh ${ }^{2}$, Fitriyani $^{3}$, Wulan Agustin Ningrum ${ }^{4}$ \\ ${ }^{1234}$ Farmasi, Fakultas Ilmu Kesehatan, Universitas Muhammadiyah Pekajangan Pekalongan \\ Jl. Raya Ambokembang No.08 Pekajangan-Pekalongan \\ Email : viyamalia123@gmail.com (081542465705)
}

Submitted: 14 Agustus 2020 Received: 28 Agustus 2020 Accepted: 20 September 2020

\begin{abstract}
ABSTRAK
Kelurahan Panjang Wetan Kota Pekalongan merupakan salah satu daerah di wilayah pesisir yang rawan terhadap kejadian bencana banjir rob. Salah satu dampak signifikan banjir rob adalah timbulnya penyakit jamur kulit. Respon seseorang apabila merasakan sakit yaitu dengan melakukan tindakan mengobati sendiri (swamedikasi). Perilaku swamedikasi dipengaruhi oleh persepsi seseorang terhadap suatu penyakit. Penelitian ini bertujuan untuk mengetahui hubungan persepsi tentang penyakit jamur kulit terhadap perilaku swamedikasi di Kelurahan Panjang Wetan Kota Pekalongan tahun 2020. Jenis penelitian ini adalah non eksperimental dengan metode deskriptif korelatif. Desain penelitian menggunakan desain potong lintang (cross-sectional). Jumlah sampel dihitung dengan rumus Wibisono diperoleh 96 responden. Teknik pengambilan sampel menggunakan purposive sampling. Data diambil dengan menggunakan lembar kuesioner yang telah tervalidasi, terdiri dari penyataan persepsi tentang penyakit jamur kulit dan perilaku swamedikasi. Persepsi dan perilaku di kategorikan baik dan buruk. Data yang diperoleh kemudian dilakukan pengolahan dan analisis data. Hasil penelitian menunjukkan bahwa $71,9 \%$ responden memperoleh informasi untuk melakukan swamedikasi berasal dari pengalaman pribadi atau keluarga; penyakit jamur kulit yang pernah dialami akibat rob ialah kutu air (tinea pedis) (97,9\%); obat yang digunakan ialah salep $88^{\circledR}(33,3 \%)$, salep $24^{\circledR}(31,3 \%)$, soffel ${ }^{\circledR}(13,5 \%)$. Persepsi responden tentang penyakit jamur kulit dengan katagori buruk sebanyak 68,8\%. Perilaku swamedikasi responden dengan katagori buruk sebanyak $51 \%$. Berdasarkan analisis menggunakan uji chi square menunjukkan $\mathrm{p}=0,563(\mathrm{p}>0,05)$, tidak terdapat hubungan antara persepsi tentang penyakit jamur kulit terhadap perilaku swamedikasi $p=0,563(\mathrm{p}>0,05)$.
\end{abstract}

Kata kunci : persepsi, perilaku swamedikasi, penyakit jamur kulit

\begin{abstract}
Panjang Wetan Village Pekalongan City is is one of the coastal areas which is prone to tidal flood disasters. One of the significant impacts of tidal flooding is the emergence of skin fungal diseases. A person's response when he feels pain is to take self-medication. Selfmedicated behavior is influenced by a person's perception of a disease. This study aims to determinate the perception correlation of fungal skin disease on the self-medicated behavior in the Panjang Wetan Village Pekalongan City in 2020. This type of research is non
\end{abstract}


experimental with a descriptive correlative method. The study design uses a cross sectional design. The number of samples calculated by the Wibisono formula obtained 96 respondents. The sampling technique used purposive sampling. The data were collected using a validated questionnaire, consisting of a statement of perceptions about skin fungal diseases and selfmedicated behavior. Perception and behavior are categorized as good and bad. The data obtained were then processed and analyzed data. The results showed that $71.9 \%$ of respondents obtained information to do self-medication from personal or family experiences; skin fungal disease that has ever been experienced due to tinea versicolor is water fleas (tinea pedis) $(97.9 \%)$; the drugs used were salep $88^{\circledR}$ (33.3\%), salep $24^{\circledR}(31.3 \%)$, soffel ${ }^{\circledR}(13.5 \%)$. Respondents' perceptions about skin fungal diseases with a bad category were $68.8 \%$. The self-medicated behavior of respondents in the bad category were $51 \%$. Based on the analysis using the chi square test showed $\mathrm{p}=0.563$ ( $\mathrm{p}>0.05$ ), there was no relationship between perceptions of skin fungal disease and self-medicated behavior $\mathrm{p}=0.563(\mathrm{p}>0.05)$.

Keywords: perception, self-medicated behavior, fungal skin disease

\section{Penulis korespondensi:}

Viya Amalia

Universitas Muhammadiyah Pekajangan Pekalongan

Jl. Raya Ambokembang No.08 Pekajangan-Pekalongan

Email : viyamalia123@gmail.com (081542465705)

\section{PENDAHULUAN}

Indonesia merupakan negara dengan wilayah pesisir yang rawan terhadap bencana. Salah satu bencana yang mengancam wilayah pesisir Indonesia yaitu banjir rob (Marfai, 2014). Fenomena banjir rob telah membawa dampak bagi daerah pesisir. Salah satu dampak yang ditimbulkan akibat banjir rob ialah masalah kesehatan dengan timbulnya berbagai macam penyakit. Salah satunya yaitu penyakit kulit dikarenakan kerusakan sistem sanitasi dan air bersih (Faiqoh, 2017). Kelurahan Panjang Wetan Kota Pekalongan merupakan salah satu wilayah yang rentan terhadap kejadian banjir rob. Berdasarkan hasil wawancara dengan masyarakat setempat, fenomena banjir rob yang terjadi di wilayah Kelurahan Panjang Wetan telah membawa dampak yang signifikan, salah satunya adalah timbulnya penyakit jamur kulit.

Salah satu penyakit kulit yang bisa timbul akibat banjir rob ialah penyakit jamur kulit. Penyakit jamur kulit merupakan salah satu jenis penyakit kulit yang di sebabkan oleh infeksi jamur. Faktor yang memicu terjadinya penyakit kulit adalah kebiasaan hidup tidak bersih (Wulan dkk, 2015). Prevalensi penyakit jamur kulit mencapai 2,93-27,6\% pada tahun 2009-2011. Penyakit jamur kulit tidak menyebabkan kondisi fatal, namun karena bersifat kronik dan residif serta tidak sedikit yang resisten dengan obat antijamur, maka penyakit ini dapat menyebabkan gangguan kenyamanan dan menurunkan kualitas hidup bagi penderitanya (Pravitasari dkk, 2019).

Timbulnya penyakit jamur kulit yang dialami masyarakat, mendorong masyarakat untuk melakukan respon terhadap penyakit tersebut. Salah satu respon seseorang apabila merasakan sakit yaitu dengan melakukan tindakan mengobati sendiri (swamedikasi) (Notoatmodjo, 2010). Swamedikasi merupakan pemilihan dan penggunaan obat modern, herbal, maupun obat tradisional oleh seorang individu untuk mengatasi penyakit atau gejala penyakit (WHO, 2010). Swamedikasi atau pengobatan sendiri merupakan perilaku kesehatan individu yang berhubungan dengan pencarian pegobatan (Health Seeking Behaviour) (Wawan dan Dewi, 2014). Menurut teori Health Belief Model (HBM), salah satu faktor yang dapat mempengaruhi perilaku kesehatan individu adalah persepsi dan kepercayaan individu terhadap suatu penyakit (Priyoto, 2014). Oleh karena itu perlu dilakukan penelitian untuk mengetahui hubungan persepsi tentang penyakit jamur kulit terhadap perilaku swamedikasi di Kelurahan Panjang Wetan Kota Pekalongan tahun 2020. 


\section{METODE PENELITIAN}

Jenis penelitian ini adalah non eksperimental dengan metode deskriptif korelatif. Desain penelitian menggunakan desain potong lintang (cross-sectional). Alat pengumpulan data yang digunakan adalah kuesioner yang telah tervalidasi. Kuesioner terdiri dari 3 bagian yang meliputi karakteristik responden, persepsi tentang penyakit jamur kulit, dan perilaku swamedikasi. Kuesioner bagian persepsi tentang penyakit jamur kulit terdapat 7 pernyataan, sedangkan bagian perilaku swamedikasi terdapat 12 pernyataan. Skala pengukuran yang digunakan untuk mengukur persepsi masyarakat tentang penyakit jamur kulit yaitu skala likert. Kuesioner ini disediakan jawaban "Sangat Setuju", "Setuju", "Tidak Setuju", dan "Sangat Tidak Setuju". Pernyataan favorable jawaban "Sangat Setuju" diberi nilai 4, "Setuju" diberi nilai 3, "Tidak Setuju" diberi nilai 2, dan "Sangat Tidak Setuju" diberi nilai 1. Pada pernyataan unfavorable jawaban "Sangat Setuju" deberi nilai 1, "Setuju" diberi nilai 2, "Tidak Setuju" diberi nilai 3, dan "Sangat Tidak Setuju" diberi nilai 4. Sedangkan skala pengukuran yang digunakan untuk mengukur perilaku swamedikasi antijamur yaitu skala guttman. Kuesioner ini disediakan jawaban "Ya" dan "Tidak". Kuesioner dengan pilihan jawaban "Ya" diberi nilai 1 dan "Tidak" diberi nilai 0 pada pernyataan favorable. Sedangkan kuesioner dengan pilihan jawaban "Ya" diberi nilai 0 dan "Tidak" diberi nilai 1 pada pernyataan unfavorable.

Pembagian kategori berdasarkan cut off point, bila distribusi data normal digunakan nilai mean. Jadi persepsi tentang penyakit jamur kulit dan perilaku swamedikasi dikatakan baik bila $>$ mean, kategori tidak baik (buruk) bila $\leq$ mean. Bila distribusi data tidak normal digunakan nilai median. Jadi persepsi tentang penyakit jamur kulit dan perilaku swamedikasi dikatakan baik bila $>$ median, kategori tidak baik (buruk) bila $\leq$ median.

\section{Jalannya Penelitian}

Sampel yang digunakan dalam penelitian ini adalah masyarakat Kelurahan Panjang Wetan Kota Pekalongan yang masuk kedalam kriteria inklusi. Teknik pengambilan sampel dengan metode purposive sampling. Kriteria pemilihan sampel pada penelitian ini didasarkan pada 2 kriteria :

a. Kriteria Inklusi

1) Pernah melakukan swamedikasi penyakit jamur kulit

2) Berusia 17-60 tahun

3) Bisa membaca dan menulis

b. Kriteria Ekslusi

1) Tidak bersedia menjadi responden

2) Mempunyai penyakit kulit lain, seperti infeksi bakteri

Besarnya sampel yang digunakan dalam penelitian ini untuk jumlah populasi yang tidak diketahui menggunakan perhitungan menurut Wibisono dalam Akdon dan Riduwan (2013) sebagai berikut:

$$
\mathrm{n}=\left[\frac{\mathrm{Z} \alpha / 2 . \sigma}{e}\right]^{2}=\left[\frac{(1,96)(0,25)}{0,05}\right]^{2}=96,04
$$

Keterangan $: \mathrm{n}=$ Ukuran sampel

$\mathrm{Z}_{\alpha}=\alpha=0,05$, maka $\mathrm{Z} 0,05=1,96$

$\sigma=$ Standar deviasai populasi $=0,25$

$\mathrm{e}=$ Tingkat kesalahan

Pada penelitian ini ditetapkan bahwa tingkat kesalahan sebesar 5\% $(0,05)$ dan derajat kepercayaan sebesar 95\%. Bedasarkan perhitungan tersebut diperoleh hasil sebesar 96,04, sehingga sampel yang digunakan dalam penelitian ini sebesar 96 responden. 


\section{Analisis Data}

Data yang diperoleh dilakukan analisis univariat menggunakan SPSS untuk melihat distribusi frekuensi masing-masing variabel. Kemudian dilakukan analisis bivariat menggunakan uji chi square untuk melihat hubungan persepsi tentang penyakit jamur kulit terhadap perilaku swamedikasi.

\section{HASIL DAN PEMBAHASAN}

Penelitian ini dilakukan di Kelurahan Panjang Wetan Kota Pekalongan pada tanggal 30 Mei-12 Juni 2020. Jumlah sampel yang digunakan sebanyak 96 responden yang diambil dari RW 04, RW 05, RW 06, RW 07, RW 10, dan RW 11 di Kelurahan Panjang Wetan.

\section{Karakteristik Responden}

Karakteristik sodiodemografi responden menunjukkan bahwa responden berjenis kelamin perempuan $(65,6 \%)$, berusia 50-60 tahun $(39,6 \%)$, berstatus menikah $(92,7 \%)$, pendidikan terakhir SD $(38,5 \%)$, pekerjaan sebagai ibu rumah tangga $(36,5 \%)$, jumlah pendapatan $<1.500 .000,00(32,3 \%)$, penyakit jamur kulit yang sedang/pernah dialami yaitu kutu air $(97,9 \%)$, sumber informasi melakukan swamedikasi berasal dari pengalaman pribadi atau keluarga $(71,9 \%)$, dan obat yang digunakan dalam swmaediksi penyakit jamur kulit yaitu salep $88^{\circledR}(33,3 \%)$, salep $24^{\circledR}(31,3 \%)$, soffel $^{\circledR}(13,5 \%)$. Karakteristik sodiodemografi responden seperti pada Tabel 1 .

Tabel I. Data Karakteristik Responden

\begin{tabular}{|c|c|c|c|}
\hline No & Variabel & Jumlah (N) & Persentase (\%) \\
\hline \multirow[t]{3}{*}{1.} & Jenis kelamin & & \\
\hline & Laki-laki & 33 & 34,4 \\
\hline & Perempuan & 63 & 65,6 \\
\hline \multirow[t]{5}{*}{2.} & Usia & & \\
\hline & 17-27 tahun & 5 & 5,2 \\
\hline & 28-38 tahun & 19 & 19,8 \\
\hline & 39-49 tahun & 34 & 35,4 \\
\hline & 50-60 tahun & 38 & 39,6 \\
\hline \multirow[t]{3}{*}{3.} & Status pernikahan & & \\
\hline & Menikah & 89 & 92,7 \\
\hline & Belum menikah & 7 & 7,3 \\
\hline \multirow[t]{5}{*}{4.} & Pendidikan terakhir & & \\
\hline & SD & 37 & 38,5 \\
\hline & SLTP & 19 & 19,8 \\
\hline & SLTA & 33 & 34,4 \\
\hline & Perguruan tinggi & 7 & 7,3 \\
\hline \multirow[t]{8}{*}{5.} & Pekerjaan & & \\
\hline & Ibu rumah tangga & 35 & 36,5 \\
\hline & Nelayan & 2 & 2,1 \\
\hline & Buruh & 27 & 28,1 \\
\hline & Tidak bekerja & 5 & 4,2 \\
\hline & Wiraswasta & 9 & 9,4 \\
\hline & Guru honorer & 1 & 1,0 \\
\hline & Karyawan swasta & 3 & 3,1 \\
\hline
\end{tabular}




\begin{tabular}{|c|c|c|c|}
\hline & Pegawai BUMN & 1 & 1,0 \\
\hline & Dagang & 12 & 12,5 \\
\hline & Karyawan took & 1 & 1,0 \\
\hline \multirow[t]{6}{*}{6.} & Jumlah pendapatan (Rupiah) & & \\
\hline & $<1.500 .000,00$ & 31 & 32,3 \\
\hline & $1.500 .000,00-2.500 .000,00$ & 24 & 25,0 \\
\hline & $2.500 .000,00-3.500 .000,00$ & 1 & 1,0 \\
\hline & $>3.500 .000,00$ & 4 & 4,2 \\
\hline & Tidak memiliki pendapatan & 36 & 37,5 \\
\hline \multirow[t]{3}{*}{7.} & $\begin{array}{l}\text { Penyakit jamur kulit yang } \\
\text { sedang/pernah dialami : }\end{array}$ & & \\
\hline & Kutu air & 94 & 97,9 \\
\hline & Panu & 2 & 2,1 \\
\hline \multirow[t]{4}{*}{8.} & $\begin{array}{l}\text { Sumber informasi melakukan } \\
\text { swamedikasi }\end{array}$ & & \\
\hline & Media massa & 2 & 2,1 \\
\hline & Teman-teman dan tetangga & 25 & 26,0 \\
\hline & $\begin{array}{l}\text { Pengalaman pribadi atau } \\
\text { keluarga }\end{array}$ & 69 & 71,9 \\
\hline \multirow[t]{13}{*}{9.} & $\begin{array}{l}\text { Obat yang digunakan dalam } \\
\text { swamedikasi penyakit jamur } \\
\text { kulit }\end{array}$ & & \\
\hline & Salep $88^{\circledR}$ & 32 & 33,3 \\
\hline & Salep $24^{\circledR}$ & 30 & 31,3 \\
\hline & Soffel $^{\circledR}$ & 13 & 13,5 \\
\hline & Salep pikangsuang ${ }^{\circledR}$ & 7 & 7,3 \\
\hline & Kalpanax $^{\circledR}$ & 5 & 5,2 \\
\hline & Salep wangi ${ }^{\circledR}$ & 2 & 2,1 \\
\hline & Salep ultrasilin & 2 & 2,1 \\
\hline & Miconazole krim & 1 & 1,1 \\
\hline & $\operatorname{Betadin}^{\circledR}$ & 1 & 1,1 \\
\hline & Desoximetason krim & 1 & 1,0 \\
\hline & Alcohol $70 \%$ & 1 & 1,0 \\
\hline & Salep pagoda ${ }^{\circledR}$ & 1 & 1,0 \\
\hline
\end{tabular}

Berdasarkan Tabel I menunjukkan bahwa lebih banyak responden yang berjenis kelamin perempuan $(65,6 \%)$. Menurut Cho (2013) menyatakan bahwa perempuan lebih sering melakukan pengobatan dibandingkan dengan laki-laki, sedangkan menurut Lukovic (2014) meyatakan bahwa perempuan menganggap bahwa dengan melakukan pencegahan dan pengobatan menggunakan obat lebih efektif serta perempuan memperhatikan biaya dan efektivitas obat yang digunakan. usia responden menunjukkan bahwa lebih banyak responden berusia 50-60 tahun (39,6\%). Berdasarkan hasil tersebut, lebih banyak responden masuk dalam kategori usia dewasa. Karena menurut Skatcher-Baker menyatakan bahwa usia dewasa merupakan semua orang yang berusia $\geq 18$ th yang dianggap mempunyai kapasitas untuk membuat suatu keputusan terhadap kesehatan individu dan dapat bertanggungjawab terhadap keputusan tersebut.

Berdasarkan tingkat pendidikan menunjukkan bahwa lebih banyak responden dengan pendidikan terakhir SD. Menurut Utaminingrum, dkk (2015), perbedaan persepsi 
terkait dengan perilaku swamedikasi dapat dibentuk salah satunya oleh latar belakang pendidikan. Hasil penelitian yang didapat sesuai dengan Hidayati (2017) yang menyatakan bahwa tingkat pendidikan yang rendah dapat berpengaruh terhadap masyarakat untuk melakukan swamedikasi daripada pergi berobat ke dokter. Berdasarkan karakteristik pekerjaan menunjukkan bahwa lebih banyak responden berstatus sebagai ibu rumah tangga. menurut Rahmayanti (2017), ibu rumah tangga merupakan bagian integral dalam penyelenggaraan rumah tangga dan memiliki kepekaan yang lebih besar dalam melakukan pencarian pengobatan. Menurut Notoatmodjo (2010), pekerjaan berpengaruh terhadap proses mengakses informasi yang dibutuhkan terhadap sebuah objek. Berdasarkan karakteristik jumlah pendapatan menunjukkan bahwa lebih banyak responden yang tidak memiliki pendapatan. Hal tersebut dikarenakan sebagian besar responden adalah ibu rumah tangga sehingga tidak memiliki pendapatan. Menurut Hilda (2018) menyatakan bahwa masyarakat yang berpendapatan rendah dan tidak memiliki penghasilan menganggap bahwa dengan melakukan pengobatan sendiri lebih mudah dan praktis tanpa perlu pergi ke dokter. Selain itu menurut Anis (2017) meyatakan bahwa apabila pendapatan seseorang tinggi maka semakin baik pula perilaku swamedikasi yang dilakukan.

Jenis penyakit jamur kulit yang sedang/pernah dialami menunjukkan bahwa lebih banyak responden pernah mengalami kutu air akibat banjir rob (97,9\%). Berdasarkan penelitian yang dilakukan oleh Faiqoh, dkk (2017) menunjukkan hasil bahwa jenis penyakit yang berhubungan dengan rob terbanyak adalah kutu air. Penyakit kutu air terjadi di sebagian besar masyarakat Kelurahan Panjang Wetan dikarenakan kaki yang sering terendam air rob dalam melakukan aktivitas sehari-hari. Air rob yang kotor tersebut dapat menyebabkan masyarakat terkena penyakit kutu air.

Berdasarkan sumber infromasi yang diterima responden untuk melakukan swamedikasi berasal dari pengalaman pribadi atau keluarga. Pengalaman swamedikasi penyakit jamur kulit sebagian besar responden berasal dari saudara kandung dan orang tua. Menurut Notoadmodjo (2010), keluarga merupakan salah satu pendorong dan faktor pendorong seseorang untuk melakukan tindakan pengobatan. Sedangkan pengalaman menurut Mubarak (2011), pengalaman merupakan kejadian yang dialami individu atau seseorang pada masa lalu. Semakin banyak pengalaman seseorang maka semakin bertambah pengetahuan yang diperoleh.

Obat yang penah digunakan responden dalam swamedikasi penyakit jamur kulit menunjukkan hasil bahwa lebih banyak responden menggunakan salep $88^{\circledR}(33,3 \%)$, salep $24^{\circledR}(31,3 \%)$, soffel ${ }^{\circledR}(13,5 \%)$ untuk mengobati penyakit jamur kulit yang mereka alami. Berdasarkan harga, obat-obat tersebut karena harganya terjangkau dan banyak tersedia di warung. Komposisi yang tertera di kemasan, salep $88^{\circledR}$ mengandung asam salisilat, natrium benzoate, dan sulfur praecipitacum, sedangkan salep $24^{\circledR}$ mengandung asam salisilat dan sulfur praecipitacum. Kedua obat tersebut memiliki manfaat untuk mengobati penyakit jamur kulit seperti kutu air, panu, dan kadas. Akan tetapi masih banyak responden yang menggunakan obat-obat diluar agen antijamur untuk mengobati penyakit jamur yang mereka alami. Hal tersebut dikarenakan obat-obat tersebut mudah diperoleh, selain itu mereka merasa bahwa dengan menggunakan obat tersebut, penyakit jamur kulit yang mereka alami dirasa sudah sembuh.

\section{Gambaran Persepsi Tentang Penyakit Jamur Kulit}

Persepsi merupakan kemampuan otak dalam menerjemahkan stimulus atau proses untuk menerjemahkan stimulus yang masuk kedalam alat indra manusia. Persepsi manusia terdapat perbedaan sudut pandang dalam hal pengindraan. Setiap orang ada yang mempersepsikan sesuatu itu baik atau persepsi yang besifat positif maupun persepsi negatif yang akan mempengaruhi tindakan manusia yang tampak atau nyata (Donsu, 2017). Gambaran persepsi tentang penyakit jamur kulit disajikan pada Tabel II, sebagai berikut:

Tabel II. Distribusi Frekuensi Persepsi Tentang Penyakit Jamur Kulit 


\begin{tabular}{ccc}
\hline Persepsi & Jumlah (N) & Persentase (\%) \\
\hline Baik & 30 & 31,2 \\
Buruk & 66 & 68,8 \\
\hline Total & 96 & 100 \\
\hline
\end{tabular}

Pada Tabel II menunjukkan bahwa responden dengan persepsi yang buruk tentang penyakit jamur kulit sebanyak $68,8 \%$. Persepsi yang diteliti meliputi persepsi keseriusan, persepsi kerentanan, persepsi manfaat, dan persepsi hambatan. Menurut teori Heath Belief Model (HBM) dalam Priyoto (2014) persepsi individu dipengaruhi oleh variabel modifikasi seperti budaya, tingkat pendidikan, pengalaman masa lalu, keterampilan, tingkat sosial ekonomi, norma, dan motivasi, sedangkan menurut Donsu (2017) menyatakan bahwa persepsi dipengaruhi oleh pengetahuan seseorang mengenai suatu objek.

Persepsi yang buruk dari sebagian besar responden tersebut kemungkinan terjadi karena karakteristik responden sebagian besar berpendidikan rendah, tidak berpenghasilan atau berpenghasilan rendah. Penelitian oleh Bandura menyatakan bahwa pendidikan seseorang berpengaruh terhadap persepsi yang dapat membentuk perilaku sehat (Sakinah, 2017), sedangkan menurut Budiman (2013) menyatakan bahwa pendidikan mempengaruhi pengetahuan seseorang tentang kesehatan. Penelitian oleh Fauziah menyatakan bahwa terdapat hubungan antara penghasilan dan motivasi terhadap persepsi individu (persepsi keseriusan, kerentanan, manfaat, dan hambatan) (Fauziah (2015).

\section{Gambaran Perilaku Swamedikasi}

Swamedikasi merupakan pemilihan dan penggunaan obat modern, herbal, maupun obat tradisional oleh seorang individu untuk mengatasi penyakit atau gejala penyakit (WHO, 2010). Sedangkan menurut Harahap (2017) swamedikasi atau pengobatan sendiri adalah bagian dari upaya masyarakat untuk menjaga kesehatannya sendiri. Swamedikasi merupakan perilaku kesehatan individu yang berhubungan dengan pencarian pegobatan (Health Seeking Behaviour) (Wawan dan Dewi, 2014). Gambaran perilaku swamedikasi disajikan pada Tabel III, sebagai berikut:

Tabel III. Distribusi frekuensi perilaku swamedikasi

\begin{tabular}{ccc}
\hline Perilaku Swamedikasi & Jumlah (N) & Persentase (\%) \\
\hline Baik & 47 & 49,0 \\
Buruk & 49 & 51,0 \\
\hline Total & 96 & 100
\end{tabular}

Pada Tabel III menunjukkan bahwa responden dengan perilaku swamedikasi buruk sebanyak $51 \%$. Perilaku swamedikasi yang diteliti meliputi bagian pengetahuan, sikap, dan tindakan. Menurut teori Heath Belief Model (HBM), perilaku kesehatan individu dipengaruhi oleh persepsi dan kepercayaan individu tanpa memandang apakah persepsi dan kepercayaannya sesuai atau tidak sesuai dengan realitanya (Priyoto, 2014). Perilaku swamedikasi responden sebagian besar masuk dalam kategori buruk dikarenakan persepsi sebagian responden masuk dalam kategori buruk. Perilaku yang buruk dari sebagain besar responden menyebabkan masih banyak kesalahan yang dilakukan responden saat melakukan pengobatan sendiri penyakit jamur kulit. Menurut Jajuli (2018) menyatakan bahwa pada kesalahan yang terjadi pada pengobatan swamedikasi dapat memicu timbulnya Adverse 
Drug Reaction (ADR) yang dapat menimbulkan kerugian bagi tubuh, sehingga masyarakat perlu mengetahui informasi pengobatan yang benar.

\section{Hubungan antara Persepsi Tentang Penyakit Jamur Kulit Terhadap Perilaku Swamedikasi}

Hubungan antara persepsi tentang penyakit jamur kulit dengan perilaku swamedikasi dapat dilihat dengan hipotesis nol $\left(\mathrm{H}_{0}\right)$ yaitu tidak terdapat hubungan antara persepsi tentang penyakit jamur kulit terhadap perilaku swamedikasi dan hipotesis alternative $\left(\mathrm{H}_{1}\right)$ yaitu terdapat hubungan antara persepsi tentang penyakit jamur kulit terhadap perilaku swamedikasi. Hasil analisis chi square hubungan antara persepsi tentang penyakit jamur kulit dengan perilaku swamedikasi, dapat dilihat pada Tabel IV.

Tabel IV. Hubungan antara persepsi tentang penyakit jamur kulit terhadap perilaku swamedikasi menggunakan uji chi square

\begin{tabular}{lcccc}
\hline \multirow{2}{*}{ Variabel } & & \multicolumn{2}{c}{ Perilaku } & p value \\
\cline { 3 - 4 } & & $\begin{array}{c}\text { Baik } \\
(\%)\end{array}$ & $\begin{array}{c}\text { Buruk } \\
(\%)\end{array}$ & \\
\hline \multirow{2}{*}{ Persepsi } & Baik & 53,3 & 46,7 & 0,563 \\
& & & & \\
& Buruk & 47,0 & 53,0 & \\
\hline
\end{tabular}

Berdasarkan hasil analisis data menggunakan uji chi square, diperoleh nilai $p=0,563$ dengan taraf kepercayaan $95 \%$, sehingga dapat dikatakan tidak ada hubungan antara persepsi tentang penyakit jamur kulit terhadap perilaku swamedikasi. Berdasarkan teori Health Belief Model (HBM), perilaku individu dipengaruhi oleh persepsi dan kepercayaan individu tanpa memandang apakah persepsi dan kepercayaannya sesuai atau tidak sesuai dengan realitanya. Selain itu menurut teori Heath Belief Model (HBM) menyebutkan bahwa selain faktor persepsi, perilaku juga dipengaruhi oleh isyarat untuk bertindak. Isyarat untuk bertindak merupakan peristiwa-peristiwa, orang, atau hal-hal yang menggerakkan orang untuk mengubah perilaku mereka. Isyarat untuk bertindak dapat berasal dari informasi dari media masa, nasihat dari orang-orang sekitar, pengalaman pribadi atau keluarga, artikel dan lain sebagainya. (Priyoto, 2014). Selain faktor persepsi dan isyarat untuk bertindak, menurut WHO dalam Zeenot (2013), faktor-faktor penyebab seseorang melakukan tindakan swamedikasi antara lain faktor sosial ekonomi, gaya hidup, kemudahan memperoleh produk, faktor kesehatan lingkungan, dan ketersediaan produk obat

Tidak adanya hubungan antara persepsi tentang penyakit jamur kulit terhadap perilaku swamedikasi yaitu dari hasil penelitian menunjukkan bahwa kondisi sosial ekonomi sebagian responden menunjukkan bahwa tingkat pendidikan responden sebagian besar SD, tingkat pendapatan responden sebagian besar < Rp.1.500.000,00, dan pekerjaan sebagian responden berstatus ibu rumah tangga. Kemudian melihat kondisi lingkungan Kelurahan Panjang Wetan yang sering rob, menjadi faktor penghambat dalam memperoleh produk. Kondisi tersebut yang menjadi alasan sebagian besar responden tidak membeli obat di apotek, mereka lebih memilih membeli obat di warung yang dekat dengan tempat tinggal. Selain itu isyarat untuk bertindak sebagian besar responden berasal dari pengalaman pribadi atau keluarga karena berdasarkan pengalaman dengan menggunakan obat yang sama, penyakit jamur kulit yang mereka alami dirasa sudah sembuh sehingga mereka merasa bahwa tidak memerlukan informasi lebih lebih lanjut terkait pengobatan yang mereka lakukan. 


\section{KESIMPULAN}

Berdasarkan hasil penelitian menunjukkan bahwa persepsi responden tentang penyakit jamur dengan kategori buruk $68,8 \%$, perilaku swamedikasi responden dengan kategori buruk $(51,0 \%)$. Tidak terdapat hubungan antara persepsi tentang penyakit jamur kulit dengan perilaku swamedikasi $p=0,563$.

\section{UCAPAN TERIMAKASIH}

Peneliti mengucapkan terimakasih kepada BAPPEDA Kota Pekalongan, Universitas Muhammadiyah Pekajangan Pekalongan, dan masyakarat di Kelurahan Panjang Wetang

\section{DAFTAR PUSTAKA}

Budiman \& Agus, R. 2013. Kapita Selektai Kuesioner Pengetahuan Dan Sikap Dalam Penelitian Kesehatan. Jakarta: Salemba Medika.

Donsu, J.D.T. 2017. Psikologi Keperawatan. Yogyakarta: Pustaka Baru Press.

Cho, et al. 2013. The Factor Contributing To Expenditures on Over-Yhe Counter Drugs in South Korea. Public health. Seoul national university 05: 147-151.

Faiqoh, F., Sulistiyani., \& Budiyono. 2017. Analisis Hubungan Tingkat Kerentanan Penduduk Wilayah Pantai Kota Semarang Akibat Banjir Rob dengan Status Kesehatan. Jurnal Kesehatan Masyarakat, Vol 05 (05), halaman 649-658.

Fauzia, R., Titik, R., \& Eka, N. 2015. Faktor yang Mempengaruhi Perilaku Pengobatan Sendiri Pada Kelompok Ibu Rumah Tangga di Kabupaten Purwakarta Tahun 2014. Prosiding Penelitian SpeSia, halaman 11-18.

Harahap, N.A., Khairunnisa'., \& Juanita T. 2017. Tingkat Pengetahuan Pasien Dan Rasionalitas Swamedikasi di Tiga Apotek Kota Panyabungan. Jurnal Farmasi \& Klinkis, Vol 03 (02), halaman 186-192.

Hidayati, A., Haafizah, D., \& Murtyk D.P. 2017. Tingkat Pengetahuan Penggunaan Obat Bebas dan Bebas Terbatas Untuk Swamedikasi Pada Masyarakat RW 8 Morobangun Jogotirto Berbah Sleman Yogyakarta. Jurnal Ilmiah Manuntung, Vol 03 (02), halaman 139-149.

Jajuli, M., \& Rano, K, S. 2018. Artikel Tinjauan: Faktor-Faktor yang Mempengaruhi Risiko Pengobatan Swamedikasi. Farmaka, Vol.16 (01), halaman 48-53.

Lukovic, J.A., Vladimir, M., \& Tatjana, P. 2014. Self-Medication Practices and Risk Factors for Self-Medication among Medical Students in Belgrade, Serbia. Journal PLoS ONE, 9 (12), 1-14.

Marfai, M.A., ahmad C., Achmad.A.K., Luthfi, A.H., \& Dela, R.T. 2014. Dampak Bencana Banjir Pesisir dan Adaptasi Masyarakat Terhadapnya di Kabupaten Pekalongan. Makalah dalam Pekan Ilmiah Tahunan Ikatan Geograf Indonesia (PIT IGI).

Mubarak, W.I. 2011. Promosi Kesehatan. Yogyakarta: Graha Ilmu.

Notoatmodjo, S. 2010. Ilmu Perilaku Kesehatan. Jakarta: PT. Rineka Cipta. 
Pravitasari, D.N., Tubagus, A.H., Aliefia, F.N., \& Ridya, P. 2019. Jurnal Saintika Medika, Vol 15 (01), halaman 25-32.

Priyoto. 2014. Teori Sikap dan Perilaku dalam Kesehatan. Yogyakarta: Nuha Medika.

Sakinah, Z.V. 2017. Aplikasi Health Belief Model Dalam Menganalisis Perilaku Penggunaan Kacamata Pelindung. Jurnal Promkes, Vol.5 (01), halaman 105-116.

Sketcher-Baker, K. 2017. Guide to Informed Decision-Making in Health Care $2^{\text {nd }}$ Ed. Queensland Health, 09, 67.

Utaminingrum, W., Lestari, J,E., \& Kusuma A,M. 2015. Pengaruh Faktor-Faktor Sosiodemografi Terhadap Rasionalitas Penggunaan Obat Dalam Pengobatan Sendiri Pada Pasien Program Pengelolaan Penyakit Kronis (Prolanis). Farmasains, 2 (6), 285-288.

World Health Organization. 2010. Rational Use of Medication. http://www.who.int/mediacentre/facttsheets/ffs338/en/index.html. Diakses pada 10 Oktober 2019.

Wulan, A.J., Dyah, W.S., Hanna, M., \& Rekha N.I. 2015. Pengingkatan Pengetahuan dan Partisipasi Aktif di dalam Pencegahan Penyakit Jamur Pada Kulit Kepala Santri di Pondok Pesantren Jabal Annur Kecamatan Teluk Beletung Selatan Bandarlampung. JPM Ruwa Jurai, Vol 01 (01), halaman 52-56.

Zeenot, S. 2013. Pengelolaan \& Penggunaan Obat Wajib Apotek. Yogyakarta: D-Medika. 